\title{
Preparation of Tang Chang'an Persian Studies
}

\author{
Jumei Li \\ Institute of Silk Road Studies \\ Northwest University \\ Xi'an, China 710069
}

\begin{abstract}
This electronic document is a "live" template and already defines the components of your paper [title, text, heads, etc.] in its style sheet. The Tang Dynasty was the most prosperous dynasty of foreign exchange in Chinese history. During the Sui and Tang dynasties, China and the Westerners including Persia exchanged achievements in the development of civilization between the East and the West. Take the Persians of the Western Regions as an example. During this period, various Persians entered China and took root in Changan, bringing with them the material spiritual civilization of the West. The compatriots' brilliance of the Tang Dynasty drew the attention of Persians from all walks of life. From the literature and archaeological data as well as the research results of senior teachers, the article discusses political envoys, commercial trade, religious culture, and living areas. It reveals that Chang'an Persians had affected the differences in their living areas due to differences in their identities. As the degree of Hanization deepens, the Persians in Chang'an gradually integrate into the social life of China. At the same time, it also promoted the internationalization of Chang'an.
\end{abstract}

\section{Keywords-Tang Dynasty; Chang'an; Persian; living area}

\section{INTRODUCTION}

Persian, Chinese historical records, said strip support countries, labor rest belonged to the country, for the repose of the west (Western history, namely Persia rest.) "Persian" country for the first time in Chinese history books should be slightly Wei of "Wei" in. "Wei • Western Regions" in mind. "Lee Persian capital city in places accustomed to Mississippi, Antiochia ancient country also ...... its wave of Andean Wang." For the explanation of their country of origin have different views, "Chinese and Western Transportation The compilation of historical data: Persia in ancient times was a tribe of the Yilan people, who began to grow strong in Kailash, built Achmenes and unified Western Asia, and the name of Persia became a country name.[1]

\section{POLITICAL ENVOYS}

The Sui Dynasty had completed the unification of the whole country, and the Western countries including Persia had resumed their tributary trade with China. The Chinese government had again reclaimed this area. "The emperor sent the cloud to ride the horse to make it through the Persian. The mission was to send the tribute to the party." [2]The Tang Dynasty further strengthened this diplomatic relationship. In $630 \mathrm{AD}$, Sassanian Persia was swallowed by the rapidly rising Arab Empire. However, with the name of
"West Persia", "The Nieshi division passed away for twenty years because of its guests, and the tribal people benefited from being separated. At the beginning of the Dragon King, he returned to the North and granted the left Weiwei General He died, and the west still existed. Kaiyuan, Tianbao Room, sent ten generations of envoys, offering agate beds, fire feather embroidery dance."[3] The royal family Pylus, "Shang Hengzhong entered the DPRK and granted the rightwing general Wu Wei to die." The son of Nigellus, the Nie Division teacher, served as a proton in Datang Chang'an to maintain the harmonious diplomatic relations between the two countries. The Old Tang Book • The Legend of Yi Hang contains: "Now the Persian King is in its possession, its son Nie Shishi is in Changan, and Wang Zhuo is in Persia, and Gojong is from it. The Great Diet made it." In 678, his son Nishishi was appointed king of Persia. In 708, the Nie Division teacher returned to the Tang Dynasty and was awarded the title of General Zuo Weiwei. He soon died of disease in Chang'an. In the Chinese sense, Persia has perished. As a royal family member, Pellus and his son Nie Shishi came to China's Tang Dynasty several times and was more honorable. At the same time, he should have a large number of followers. These people should be important members of the Chang'an Persians. Most of the Persian people in this period were named $\mathrm{Li}$, especially the Persian kings.[4] In this period, the purpose of these royal family envoys to China was to leave their homes and seek asylum.

Afterwards, many Persian politicians came to China. Ce Fu Yuan Gui" Book Nine contained seventy-five: Kaiyuan thirteen years to ten eight years in November, the Persian leader Musha Luo twice to changan "Give conciliation, live guard."A member of the Housekeeping Army, this was a major way for the Tang Dynasty to place foreign envoys. Su Liang, "The Exodus of the Martyr of Sue Sang and the Wife of the Marriage" written by the Chinese and the Persian Borneo in the Tumen Village of Xi'an City in 1955. The Chinese literary text is: "The left God strategy army disperses the horse soldier to make Su Liangliang's wife Ma Jisheng students", according to the studies of scholars such as Professor Ito Yoshitori and others, it shows that: Su Liang and Ma Shi were the remnants of Sassanian Persia, Xiantong fifteen In 874, when Mars died, Su was left as a soldier of the left.[5] $\mathrm{Li} \mathrm{Su}$, an epitaph of the Persian $\mathrm{Li} \mathrm{Su}$ and his wife Xianshi unearthed in the children's school playground of the Fourth National Cotton Plant of Xi'an Northwest in 1987. The content of the epitaph was extracted as follows: "The public prostitutes, the Persian people of the West, too. In Tianbao period, the public went to the calendar division 
Tianjian, Yuanhe twelve years, Dingyou times December 17 and finally died in Jing Gongli. Building a cemetery in Wannian County, Chanchuan Township, Shangchuan Village, Guantaili Township."[6] From the perspective of these two tombs unearthed in Xi'an, Su Liang was a General and $\mathrm{Li} \mathrm{Su}$ was a technical officer. However, the epitaph of $\mathrm{Li}$ $\mathrm{Su}$ also explicitly stated that his ancestor Li Yi granted silver and Qing Guanglu doctors and other military commanders. Since the beginning of the Tang Dynasty, the Tang Dynasty affiliated foreign protons and detained envoys with the generals of the central 16-guard generals and the Soda guards.[7] As mentioned earlier, both the Persian royal family and the political ambassador met this historical fact.

Of course, these politicians came to China and lived in China for a long period of time. On the one hand, they had a certain increase in the number of migrants in Chang'an. At the same time, they initially came to Chang'an and were generally given military attaching posts to defend Chang'an, which also helped to manage the security of Chang'an Foreigners. After all, these political figures had a higher status in their local society and had a stronger appeal. This was also conducive to better and closer exchanges between Chinese and Western cultures.

\section{BUSINESSMAN}

The second type of far-reaching influence was the Persian businessman. During the Sui and Tang Dynasties, the Hushang merchants, including Persia, were active in China's two major capitals and coastal cities. Most of the Persian merchants were from Hailu to China's Guangdong province and they had entered Chang'an and Luoyang in mainland China.[8] They brought rare treasures in the world, enriched China's commodity market, and promoted the exchange of material civilizations in the world. "Tang Dahe's biography of the East" contains: "Guangzhou Jiangzhong" had Brahman, Persian, Kunlun and other ships, and they did not know the number of them, and carried spices and jewellery. "The commercial activities of the Chang'an Persian traders could be reflected in historical materials such as miscellaneous records and essay fiction. In the "Old Tang Book - Jingzong": "In the fourth year of Changqing (824) September, there was a Persian businessman Li Susha enters Chen Xiang. Pavilion materials." "Youyangzazu·Zhidong" contained: "Duan maked the Pindao use a thousand Qian to go to the west city to find western businessman to ask for the wolf towel". [9] "Tai Ping Guang Ji" recorded Du Zichun's work. "Noon tomorrow, I were waiting for you in the Persian house in the West City." And it also recorded Liu Guanci : "And the rest of the year, Suddenly there was a Huke in the West City" .[10] These historical materials reflected the number of Hu people in Chang'an West, including of course a large number of Persian merchants. The Tang Dynasty West City was a major gathering place for $\mathrm{Hu}$ businesses including Persians. [11] The foreign songwriters that appeared in the poems of ancient Chinese literati together with foreign merchants represented the prevalence of the wind of Chang'an and also reflected the foreign businessmen's activities in Chang'an. Changan East city also had a large number of $\mathrm{Hu}$ Merchants activities. Wang Ji's
"Over Restaurant" cloud: ""Come always to make way, wandered by the merchants of the restaurant" Li Bai's "Before There is a Liquor Drinks" contains: "Hu Ji looks like a flower, when you laugh at the spring breeze." Li Bai "sends Pei the eighteen maps south to return to the Songshan" cloud "Where can be for nothing, Changan Qingyimen." Mr. Xiangda thought that Qingyimen was the Bacheng Gate. Japan's Takuya's Assist thinks it was the Chunmingmen of Tang. Chunmingmen called the East Gate, the east gate of Xingqingfang South Street. [12]"The complete poetry of Tang Dynasty • Hu Ji Ci" cloud: "Yan Zhao Zhao river head, spring breeze hospitality to stay." This river head to the teacher that was Qu Jiang head. The general area reflected by these literary works was from the Chunmingmen to the Qujiang area of the Tang Dynasty. These showed that there were also a large number of $\mathrm{Hu}$ Merchants activities in Chang'an East City during this period. Since they are doing business in this area, the residence should also be in this area or Adjacent to this area. It can be seen that during this period, the Hushang merchants, including the Persian businessmen, had been spreading over the cities of East and West in Chang'an. Advanced business ideas, broad business experience, and vision had made Persian merchants stand out from the crowds of merchants and had become a brighter part of Chang'an. In addition, the business model culture that included Persian merchants, such as exhortation and dance, which integrated entertainment and leisure, was also deeply loved by Chang'an. At the same time, Chang'an's business culture had also been revitalized. Such a large number of poems and miscellaneous descriptions described the special commercial culture phenomenon of Chang'an. It could also be seen that this culture, which differed from the tradition of the Central Plains, had already landed and developed in the Tang Dynasty.

\section{MONKS}

During this period, exotic religions including Nestorianism, martyrdom, etc. came to China through Persians in the East. During this period, exotic religions including Nestorianism, martyrdom, etc. came to China through Persians in the East. [13] Persian Arouben, from the period of Emperor Taizong's Zhenguan period, to the spread of Nestorianism in Chang'an, established the Daqin Temple in Yiningfang, which was regarded as the beginning of the introduction of Nestorianism into China. "Tang Hui Yao," Vol. 49: "Zhenguan July 12th. Persian Aroben. That is to build a temple in Yining Square. Its two capitals Persia Temple. Should be changed to Daqin Temple. Homeowners are also permitted." It can thus be seen that Nestorianism was introduced to China from the age of Zhenguan, and during the Tianbao years, Nestorianism had survived steadily in China. And with the support of the Chinese government, development had been rapid.

It is now included in the Daqin Nestorian Pop China Monument in Beilin, Xi'an. There are altogether 70 to 80 members of the Nestorian scriptures at the side of the monument, the side of the monument, and the inscription. They are all from the ninth year of Zhenguan (635). In the one hundred and fifty years since the founding of the 
Jianzhong monument in the second year of Jianzhong (781), the Persians were the people who were involved in the Nestorian activities in Chang'an. Moreover, the author of this monument, Jing Jing and Zhen Yuan (AD 786), was translated into seven volumes with Prajna Sanzhai's "The Six Paramita Sutras." According to experts and scholars, Jing Jing is also Persian. The Old Persian Temple is on the South of the East of LiquanFang.

In the same period, Persians taught to teach in Persians. Zoroastrian temples were mainly distributed in the West city, according to the "Liang jing xin ji" volume three contained: "Xijing Buzheng Square, southwest corner, Zoroastrian temple." Liquan Square: "Northwest corner, Zoroastrian temple."Puning Square: "Northwest corner, Zoroastrian temple." Jinggong Square: "West of the street, Zoroastrian temple" .[14] Most of these temples were located around the city of East city, which should be positively related to the settlement of foreign people in the West City. These differed from Chang'an's indigenous Taoism and already localized Buddhism's religious beliefs, which could be seen in the larger scale of Changan's popularity. The bold and open mind of the Tang Empire and the pattern of compatibility and integration.

\section{CHANG'AN PERSIAN AREA OF ACTIVITY}

Political ambassadors were generally awarded military commanders to defend the capital. Their residences were generally located in the neighborhoods of the West city, and religious sites were also distributed around the streets of the West city. The tombs of these military commanders and religious figures were also mostly in the western suburbs of Changan,such as Longshou Township, Xiaoti Township. such as Su Liang Tomb; An Shuguo: "Tang Weizhou Cishi anhou Tablet" contains: The name of Anhou isFuguo. It first came from rest and took the country as its surname. In the 19 years of Zhenguan, the public opinion was on the column state and the founding father of Fengxian County had jurisdiction over three hundred families." residence in Liquan Square, burial place in Longshouyuan, Chang'an County; An Wantong, "Tang'an Wantong Brick Epitaph "set: Their ancestors out of this Western Parthian, finally Chang'an Puning Square, buried with the Longshouyuan in the west of the city. According to archaeological datas, the Persian inhabitants of these vagrants were found in various places around the city. The cemetery was also in Xitumen Village, Zaoyuan Village and Yanzhuang Village around 30 $\mathrm{km}$ west of Kaiyuanmen in the western suburbs of Xi'an.[15]

The excavation of Li Su's tomb showed that his house was in East city, and its cemetery was Shangchuan Village in Jingchuan Township, Wannian County, and it was located in Guojiatan, Yongqiao District, Xi'an City. The "Chinese Heritage Atlas" in Shaanxi Booklet: The tombs of the Tang Dynasty unearthed in Xi'an were mainly distributed in Hansenzhai, Xinjiao District, Guojiatan, Shilipu Gaolou, Zhangjiagou and Tianjiawan in the eastern suburbs of $\mathrm{Xi}$ 'an.The majority of the tombs unearthed in this area were official residences, probably due to their proximity to Daming Palace and Xingqing Palace. Dignitaries mostly lived in front of each East Market Square, the "China and
India travelogue" recorded: "big city with a large population, a wide long street the city is divided into two halves emperor, prime minister, imperial guards. The highest judge, the palace eunuch, the royal ruler, and the slaves live in the eastern area on the right side of the street. There are no people living in the area and they do not have any markets. In the west area on the left side of the street, there are people and businessmen."[16] This area was the political center of the Tang Dynasty. The place where officials were prominent was concentrated. Li Su's house and tomb appeared in the eastern suburbs of Dongshi. It could be seen that he had been integrated into the dignitary elite class of the Tang Dynasty.

\section{CONCLUSION}

From the perspective of the Persian class in Chang'an, there were a large number of Persians in the Tang Dynasty who came to Chang'an. According to their different strata, their living areas were also different. The official residences of civil and technical officials should be mostly in the east of the city, and the burial grounds were also in the eastern suburbs; while the generals and defenders should be in the West City Square. The Persians who entered China as protists were mostly military attaches, so their residences and cemeteries were mostly in the western suburbs west of the city. The settlement of people had also affected the distribution of their religious sites. Jingjiao Temples were also located in the West City Square. However, the merchant's business characteristics seemeed to have broken through this limitation. West and East cities had a large number of Persian Hu.

\section{REFERENCES}

[1] Zhangxing Lang. "Traffic materials documenting the West" (Volume II), Beijing: Zhonghua Book Company, 1974, pp. 1043.

[2] [Tong] Wei Zheng. "Sui book" volume eighty-three "Western Regions", Beijing: Zhonghua Book Company, 1997, p.1245.

[3] [Song] Ouyang Xiu. "New Book of Tang" Volume 221 "Western Regions", Beijing: Zhonghua Book Company, 1975, p.4747 .

[4] Han Xiang. Chang An in the Sui and Tang Dynasties and Civilizations in Central Asia. Beijing: China Social Science Press, 2006, p. 76.

[5] Han Xiang. Chang An in the Sui and Tang Dynasties and Civilizations in Central Asia. Beijing: China Social Sciences Press, 2006, p. 96.

[6] Zhou Shaoliang. "Compilation of Tang Dynasty epitaphs", Shanghai: Shanghai Ancient Books Publishing House, 1992, p. 2073-2073.

[7] Rong Xinjiang. A Persian Nestorian Family Entering the Shi Tang Dynasty, edited by Ye Shuliang: The Iranian School of Philosophy in China, Episode 2, Beijing. Peking University Press, 1998.

[8] Rong Xinjiang. "Persia and China: The Blending of Two Cultures", originally published in Liu Dong's "China Academic", Beijing: Commercial Press, 2002, p. 56-76.

[9] [Tong] Duan Chengshi. "Zhidong", taken from "Youyang zazu" Volume 9, Beijing: Zhonghua Book Company, 1981, p. 86.

[10] [Song] Du Zichun. "Continuing Mysterious Records", Li fang: "Tai Ping Guang Ji" Volume 16, Beijing: Zhonghua Book Company, 1968, p. 110.

[11] Xiang Da. "Chang'an in the Tang Dynasty and Civilization in the Western Regions”, Hebei: Hebei Education Press, 2001,p 37-41.

[12] Li Jianchao. "An Update on Two Beijing Capital Square Examinations" Volume II, San Qin Publishing House, 2006, p. 39-40. 
[13] Xiang Da. "Chang'an in the Tang Dynasty and Civilization in the Western Regions", Hebei: Hebei Education Press, 2001,p 42.

[14] [Tong] Wei Shu. Liang Jing Xin Ji, Vol. 3, Beijing: Zhonghua Book Company, 1985, p. 18

[15] Wu Bolun. "Tang Changan, Wannian County Examination", Shaanxi Province Museum, "Archaeological Journal", second issue, 1963, p. 98.

[16] Mu Genlai, Wen Jiang. Huang Yi Han translated. "China's India Record", Beijing: Zhonghua Book Company, 1983, p. 107. 